\title{
IMPLEMENTASI SISTEM PENGELOLAAN PROSES BISNIS MENGACU PADA MIT PROCESS HANDBOOK
}

\author{
Putu Wuri Handayani ${ }^{1}$, Stéphane Bressan², Doan Khanh Han², dan Omar Boucelma ${ }^{3}$ \\ ${ }^{1}$ Fakultas Ilmu Komputer, Universitas Indonesia, Kampus Baru UI, Depok, 16424, Indonesia \\ ${ }^{2}$ National University of Singapore, 21 Lower Kent Ridge Road, 119077, Singapore \\ ${ }^{3}$ Université Paul Cézanne, Aix-Marseille, 3 avenue Robert-Schuman, 13628, Aix-en-Provence cedex I \\ E-mail: putu.wuri@cs.ui.ac.id
}

\begin{abstract}
Abstrak
MIT Process Handbook menawarkan metode penyimpanan dan pencarian proses bisnis suatu organisasi. Komunitas bisnis atau mahasiswa yang mengambil topik kuliah proses bisnis dapat mempelajari best-practice proses bisnis yang terdapat dalam MIT Process Handbook. Kumpulan proses bisnis yang terdapat di MIT Process Handbook hanya mengelola deskripsi proses bisnis tersebut dalam format teks. Kemunculan teknologi Extensible Markup Language (XML), kemampuan XML dalam melakukan query, adopsi dari banyak industri untuk menggunakan standar berbasis XML dalam pendefinisian dan pengeksekusian proses bisnis serta dukungan dari sistem basis data yang sudah mendukung penyimpanan data dalam format XML memudahkan semua pihak dalam perancangan dan implementasi sistem pengelolaan bisnis proses dengan mengadopsi standar dan teknologi XML ini. Sistem pengelolaan proses bisnis ini dapat digunakan untuk mengelola, mendistribusikan, dan melakukan query terhadap proses bisnis tertentu. Penelitian ini menjelaskan mengenai rancangan dan arsitektur sistem pengelolaan proses bisnis dengan kumpulan proses bisnis yang dapat digunakan untuk mengajar mata kuliah Business Process Management di program studi Sistem Informasi.
\end{abstract}

Kata Kunci: MIT process handbook, proses bisnis, extensible markup language, XML

\begin{abstract}
MIT Process Handbook offers a method of storage and retrieval of an organization's business processes. Business community or college students who take the topic of business processes can learn best-practice business processes contained in the MIT Process Handbook. Collection of business processes that are contained in the MIT Process Handbook only manage the business process description in text. The emergence of Extensible Markup Language (XML), XML querying capabilities, adoption of many industries to use XML-based standards in the definition and execution of business processes and data base system that supports data storage in XML format facilitates all parties in the design and implementation of business process management systems by adopting these standards and XML technologies. Business process management systems can be used to manage, distribute, and perform a query against a particular business process. This study describes the design and architecture of business process management system with a collection of business processes that can be used to teach Business Process Management in Information Systems courses.
\end{abstract}

Keywords: MIT process handbook, business process, extensible markup language, XML

\section{Pendahuluan}

Workflow Management Coalition (WfMC) mendefinisikan proses bisnis sebagai kumpulan prosedur atau aktivitas yang dapat mendefinisikan objektif atau tujuan bisnis, umumnya dalam konteks struktur organisasi yang dapat mendefinisikan peranan dan hubungan fungsional pada organisasi tersebut [1]. Sejak periode Adam SMITh, seluruh organisasi telah menyadari bahwa analisa, rancangan, implementasi,dan pengelolaan proses bisnis yang tepat merupakan kunci sukses bisnis. Selain itu, proses bisnis merupakan aset dari suatu organisasi sama seperti aset lainnya yang dapat diukur dan hak kekayaan intelektual.

Saat ini beberapa organisasi, komunitas,dan individual membutuhkan bantuan dan dukungan dalam pengelolaan proses bisnis organisasi. Disamping itu, Usaha Kecil dan Menengah (UKM) membutuhkan bantuan dalam perancangan alur proses bisnis yang disesuaikan dengan katalog proses bisnis yang telah didefinisikan oleh suatu organisasi yang sudah mapan ataupun pemerintah dikarenakan 
keterbatasan biaya dalam pembuatan alur proses bisnis dari awal (from the scratch). Jaringan antar partner bisnis (contohnya supplier, transporter, dan konsumen) juga membutuhkan halaman antarmuka untuk mengkombinasikan proses bisnis yang mereka miliki sekaligus mentransformasikan ke dalam satu proses bisnis yang terintegrasi. Selain itu, mahasiswa program studi Sistem Informasi membutuhkan pemahaman yang luas dalam mempelajari proses bisnis suatu organisasi dan skenario best practice proses bisnis untuk suatu organisasi tertentu.

MIT Process Handbook [2] menawarkan metode untuk organisasi, komunitas maupun individual dalam menyimpan, mengambil dan melakukan query atas suatu proses bisnis. Objektif dari MIT Process Handbook adalah untuk membuat basis data kumpulan proses bisnis yang dapat mencerminkan proses umum yang dilakukan di suatu organisasi (misal proses pembelian, pembuatan dan penjualan). MIT Process Handbook menyediakan kerangka dalam menjelajahi dan mengklasifikasi proses bisnis yang telah didefinisikan sebelumnya. Dengan adanya kerangka tersebut dapat menolong organisasi, komunitas dan individual dalam merancang ulang proses bisnis yang sudah ada dan tidak efektif yang kemudian dapat memungkinkan kemunculan proses bisnis baru dalam organisasi tersebut (khususnya untuk organisasi yang sudah mengadopsi Teknologi Informasi dalam mendukung kegiatan operasional organisasi tersebut). Namun, MIT Process Handbook hanya mendefinisikan proses bisnis tersebut dalam format teks yang tidak memungkinkan untuk mendukung penuh dalam kolaborasi, sinkronisasi, penyebarluasan, analisa, dan eksekusi proses bisnis tersebut. Kemunculan teknologi XML dan query language XML, terdapat beberapa organisasi yang telah menggunakan standar XML dalam pendefinisian dan pengeksekusian proses bisnis, serta terdapatnya teknologi basis data yang telah mendukung XML dan query language XML memungkinkan organisasi untuk mempertimbangkan penggunaan standar XML dalam membantu kegiatan operasional organisasi untuk mencapai tujuan bisnisnya.

Penelitian ini bertujuan untuk mengembangkan sistem pengelolaan proses bisnis yang dapat digunakan untuk menyimpan dan mengambil proses bisnis dalam format XML. Juga diharapkan nantinya proses tersebut dapat dieksekusi antar partner bisnis. Selain itu, pada penelitian ini dilakukan perancangan arsitektur sistem beserta pendefinisian kumpulan kasus proses bisnis yang digunakan dalam proses belajar mengajar pada mata kuliah Sistem Informasi.

\section{Metodologi}

Berdasarkan MIT Process Handbook, proses bisnis yang digunakan dalam suatu organisasi terdiri dari sub proses (parts), properti, proses yang terkait (related process), dan partner links untuk mengeksekusi proses bisnis tersebut.

Sebagai contoh, "proses pembelian mobil" [2]: (1) Sub proses (parts) misalnya proses identifikasi konsumen potensial, identifikasi kebutuhan konsumen, menginformasikan konsumen, memproses pesanan, pengiriman produk atau jasa, melakukan pembayaran dan menjaga hubungan baik dengan konsumen. (2) Properti berfungsi menyimpan berbagai informasi yang terkait dengan suatu proses seperti berapa lama waktu yang dibutuhkan dalam mengeksekusi proses ini, berapa biaya yang dibutuhkan dalam menyelesaikan proses ini, di mana lokasi eksekusi proses ini, dan lain sebagainya. (3) Proses terkait (related processes) di mana proses yang terkait dengan proses lainnya terbagi atas tiga bagian yaitu: a) Spesialisasi, yakni bagaimana proses menjual mobil?. Kemungkinan jawaban untuk pertanyaan tersebut adalah "menjual lewat toko", "menjual langsung ke konsumen", dan lain sebagainya. (b) Paket (bundles), yakni grup dari spesialisasi terkait berdasarkan pertanyaan dasar yang mungkin ditanyakan mengenai suatu aktivitas tertentu, seperti "Bagaimana/kapan/di mana proses penjualan?", dan lain sebagainya. (c) Generalisasi, yakni jika spesialisasi dari suatu aktivitas diumpamakan sebagai anak dari suatu proses maka generalisasi menggambarkan bagan pohon dari suatu aktivitas, misalkan proses "Penjualan" memiliki dua generalisasi yaitu "Pertukaran" dan "Penyediaan". (d) Trade-off tables, yakni membandingkan perbedaan spesialisasi dalam satu paket dengan menggunakan trade-off table, sebagai contoh salah satu bagian dari proses "Penjualan" adalah "menginformasikan konsumen potensial" dan salah satu spesialisasi dari proses "menginformasikan konsumen potensial" adalah "pengiklanan". Proses "pengiklanan" memiliki paket yaitu "Bagaimana cara mengiklankan?" dan jawabannya adalah "Pengiklanan melalui media internet/koran/radio", dan lain sebagainya.

XPDL [3] merupakan standar bahasa yang berbasiskan Petri-Nets. Standar bahasa ini digunakan untuk bertukar definisi proses bisnis antar produk workflow yang menggunakan XML. Diantara beberapa bahasa eksekusi proses bisnis seperti Business Process Execution Language (BPEL) atau Yet Another Wokflow Language (YAWL), peneliti memilih untuk mengadopsi XPDL pada penelitian ini dikarenakan merupakan standar bahasa yang tepat digunakan untuk 
memodelkan proses bisnis yang tidak mengandung interaksi layanan antar aplikasi [3]. XPDL berbasiskan XPath yang dapat menyimpan dan mentransfer definisi proses seperti aktivitas, alur transisi, partisipan, sumber daya (resource), aplikasi, workflow relevant data, sistem, dan data terkait seperti tipe dan ekspresi data. Elemen utama dari XPDL ada enam, yakni Elemen $<$ Package $>$, Elemen <WorkflowProcess $>$, Elemen $<$ ActivitySet $>$, Elemen <BlockActivity>, Elemen $<$ Participant>, Elemen <DataType> dan $<$ DataField $>$ [4][5].

Elemen <Package>: Elemen <Package> adalah paket yang mendefinisikan proses bisnis. Konsep paket ini berguna untuk mengurangi definisi redundancy yang dapat digunakan untuk berbagai macam proses.

Elemen <WorkflowProcess $>$ : Elemen $<$ WorkflowProcess $>$ yaitu elemen yang digunakan untuk mendefinisikan sub proses dari suatu proses tertentu. Elemen $<$ WorkflowProcess $>$ dibagi menjadi beberapa tipe elemen, yaitu (1) Elemen <Activity> yang merupakan fondasi utama dalam pendefinisian proses bisnis. Terdapat tiga jenis aktivitas yaitu, <Route>, <BlockActivity>, dan <Implementation>. <Route> merupakan aktivitas kosong yang hanya digunakan untuk proses peralihan (routing). Sedangkan <BlockActivity> digunakan untuk mengeksekusi kumpulan kecil dari suatu aktivitas. Terakhir <Implementation> merupakan langkah implementasi proses yang ditandai dengan prosedur manual $(<\mathrm{No}\rangle)$, implementasi dengan satu atau lebih aplikasi $(<$ Tool $>$ ) atau implementasi dengan menggunakan proses workflow lainnya ( $<$ Subflow $>$ ). (2) Elemen $<$ Transition> yang menghubungkan elemen dari tipe <Activity>.

Elemen $<$ ActivitySet>: Elemen <ActivitySet> menunjukkan kumpulan dari berbagai macam aktivitas dan transisi yang menghubungkan antar aktivitas tersebut.

Elemen <BlockActivity>: Elemen $<$ BlockActivity $>$ berfungsi untuk melakukan eksekusi atas elemen $<$ ActivitySet $>$.

Elemen <Participant>: Elemen <Participant> digunakan untuk menspesifikasikan partisipan pada workflow, misalkan entitas yang dapat mengeksekusi aktivitas. Terdapat 6 tipe partisipan yaitu: <ResourceSet>, <Resource>, <Role>, $<$ OrganizationalUnit $\rangle$, <Human $>$, dan $\langle$ System $\rangle$.

Elemen <DataType $>$ dan <DataField $>$ : Elemen $<$ DataType $>$ dan $<$ DataField $>$ digunakan untuk menspesifikasikan data relevan workflow. Data ini digunakan untuk penentuan keputusan atau untuk mereferensikan data diluar dari workflow dan ditransfer ke semua aktivitas dan subflows.

Salah satu keuntungan dari penggunaan XPDL adalah proses deskripsi XML yang terdapat di XPDL dapat ditransformasikan ke dalam bentuk grafis sehingga pengguna dapat lebih mudah dan cepat untuk memahami alur proses bisnis organisasi (misalkan pada gambar $1)$.

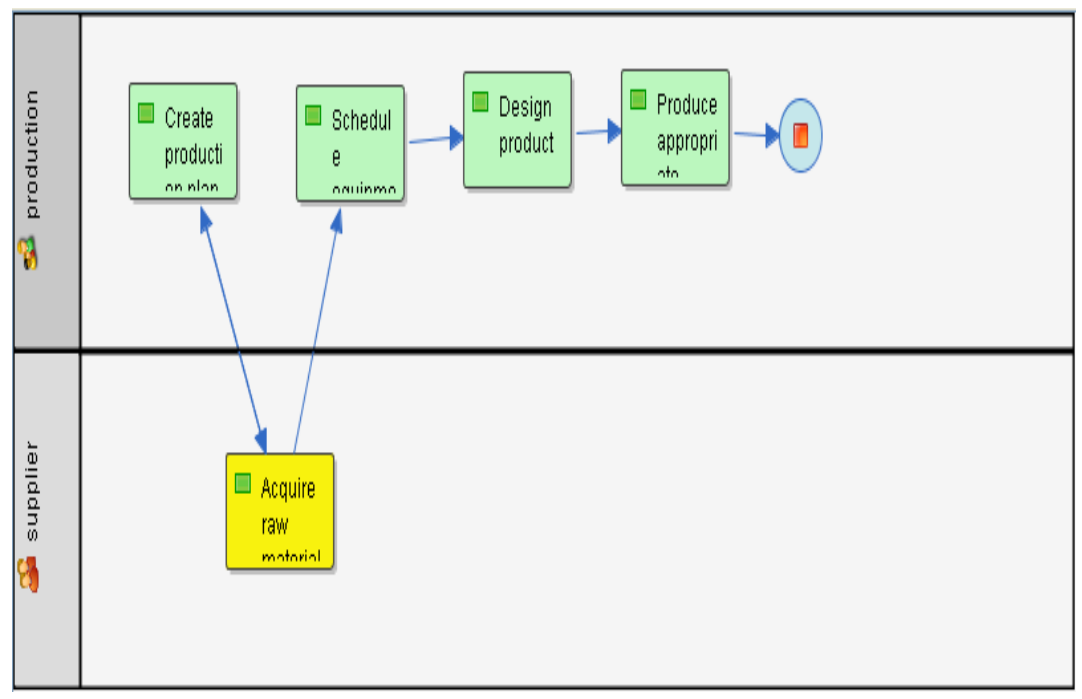

Gambar 1. Diagram XPDL proses produksi. 
Riset Terkait: Tahun 1999, MIT memperkenalkan konsep fundamental, kerangka spesifik klasifikasi, kumpulan pola proses bisnis umum, contoh kasus spesifik, dan aplikasi yang dapat digunakan untuk mengelola dan memanipulasi proses bisnis [2]. Selain itu, Wil Van Der Aalst mendefinisikan model pengelolaan wokflow, sistem dan metode yang dapat menolong pengguna dalam pengelolaan proses bisnis [5]

Saat ini terdapat beberapa standar bahasa pendefinisian proses bisnis yang umum digunakan seperti Unified Modeling Language (UML) Activity Diagram, Event-driven Process Chain (EPC), flowchart, Business Process Modelling Notation (BPMN), dan lain sebagainya. Beberapa contoh pendefinisian proses bisnis best-practice dari MIT dapat didefinisikan dengan menggunakan standar bahasa pendefinisian tersebut. Namun, standar bahasa pendefinisian proses bisnis tersebut memiliki kelemahan yaitu tidak bisa digunakan untuk melakukan eksekusi proses bisnis antar rekan bisnis. Namun kelemahan tersebut dapat diatasi seiring dengan perkembangan teknologi XML tahun 1998. Beberapa standar bahasa pengeksekusian proses bisnis yang berbasiskan XML adalah BPEL, YAWL, XPDL, dan lain sebagainya.

BPEL dikembangkan pada bulan Agustus 2002 oleh BEA, IBM, dan Microsoft. YAWL merupakan standar bahasa yang berbasiskan Petri Nets. Pada awalnya, YAWL dikembangkan oleh para peneliti dari Universitas Teknologi Eindhoven dan Universitas Queensland yang dapat digunakan untuk mendefinisikan dan mengeksekusi proses bisnis. XPDL diajukan oleh WfMC (Workflow Management Coalition) tahun 2002 dan merupakan standar bahasa yang digunakan untuk pertukaran definisi proses bisnis antar berbagai macam produk workflow. Diantara standar bahasa tersebut, XPDL merupakan standar bahasa yang paling tepat digunakan untuk mendefinisikan dan mengeksekusi proses bisnis dikarenakan XPDL memungkinkan untuk melakukan pendefinisian yang tidak terkait dengan layanan web service. Dengan kata lain, XPDL lebih fokus pada pendefinisian alur proses bisnis organisasi dan juga XPDL memperbolehkan pengembang untuk memberikan ekstensi tambahan dalam pengeksekusian proses bisnis [3]. XQuery dari W3C dapat digunakan untuk melakukan pencarian proses pada dokumen XPDL.

Penelitian lebih mendalam mengenai repositori proses bisnis dan metadata tambahan yang terkait dengan proses tersebut telah dikembangkan dengan membangun kerangka dalam penyimpanan, pencarian, dan penggunaan dokumen dalam format BPEL. Repositori ini menyediakan Java API untuk memanipulasi file XML sebagai objek Java yang dapat menutupi serialisasi dan deserialisasi dari pengguna [6]. Sebagai tambahan, Semantic Business Process Management (SBPM) telah dikembangkan dengan menggunakan teknologi semantik untuk melakukan otomatisasi melalui siklus Business Process Management (BPM). Model proses bisnis SBPM mengacu pada ontologi proses yang dapat mendukung kemampuan reasoning dan querying [7].

\section{Hasil dan Pembahasan}

Studi Kasus: Ide awal dalam pengembangan sistem pengelolaan proses bisnis ini muncul ketika semakin banyak mahasiswa dan perusahaan yang mencari dan belajar mengenai best practices proses bisnis. Hal ini menyebabkan mereka dapat mengadopsi atau mengintegrasikan proses-proses tersebut ke proses yang mereka miliki. Selain itu, mereka juga ingin mengeksekusi proses-proses tersebut melalui web service. Fitur ini sangat berguna bagi organisasi untuk berbagi, berkolaborasi, dan melakukan sinkronisasi atas proses bisnis yang mereka miliki dengan rekan bisnis lainnya.

Untuk menggunakan sistem ini, langkah awal yang harus dilakukan oleh pengguna adalah memilih pertanyaan terkait dengan proses bisnis seperti pertanyaan yang ingin menemukan proses atau sub proses, pelaksana atau partisipan terkait dengan proses bisnis tertentu, dan variabel yang digunakan pada proses bisnis tertentu.

Kumpulan pertanyaan yang digunakan dalam sistem ini adalah jenis pertanyaan terkait dengan proses bisnis yang umum dan sering ditanyakan oleh akademisi dan pihak-pihak yang terlibat dalam bisnis. Mengacu pada pertanyaan yang dipilih oleh pengguna dan kata kunci yang dimasukkan oleh pengguna ke sistem, maka sistem akan melakukan pencarian ke seluruh dokumen XPDL yang telah tersimpan dalam basis data dan kemudian hasil pencariannya ditampilkan dalam format teks maupun XML tergantung dari jenis pertanyaan yang diberikan (gambar 2).

Metode Pengajaran BPM: Contoh yang akan digunakan adalah metode pengajaran BPM. Sebelum dilakukan perancangan dan implementasi sistem pengelolaan proses bisnis, langkah awal yang dilakukan adalah melakukan pendefinisian kebutuhan awal dan daftar pertanyaan yang mungkin ditanyakan oleh akademisi dan bisnis dalam pencarian proses bisnis. Kemudian, daftar pertanyaan tersebut 
diformulasikan, diterjemahkan

dan diklasifikasikan ke dalam kalimat formal yang menggunakan bahasa Inggris. Berdasarkan daftar pertanyaan yang telah teridentifikasi, dilakukan klasifikasi untuk tiga kategori informasi yaitu informasi terkait proses atau sub proses, performer dan variabel yang dibutukkan dalam proses bisnis. Selain itu, peneliti telah mengidentifikasi 16 pertanyaan umum yang mungkin ditanyakan dalam proses bisnis. Kemudian, masing-masing pertanyaan tersebut akan diformulasikan ke dalam XQuery dalam proses pencarian.Keuntungan dari penggunaan XQuery adalah: (1) XQuery dapat melakukan query terhadap berbagai macam jenis struktur data (ekspresif). (2) XQuery dapat melakukan query terhadap data hierarki dan tabular (fleksibel).

Mengacu pada keunggulan dari XQuery dan dibandingkan dengan SQL, maka XQuery dapat mengembalikan hasil pencarian tidak hanya dalam format tabel namun juga dalam struktur pohon (tree structures). Ekspresi yang digunakan di Xquery dalam proses pencarian proses, performer dan variabel yang digunakan dalam proses bisnis adalah ekspresi Xpath dan FLWOR (For Let Where Order Return). Ekspresi Xpath memilih node atau sekumpulan node pada dokumen XML. Sementara itu, ekspresi FLOWR umumnya menggunakan perpaduan antara for dan let clauses untuk menghasilkan urutan tuple dari variable bindings, satu binding untuk masingmasing clause [8].

Di bawah ini terdapat beberapa contoh pertanyaan, query dan hasil yang diberikan terkait dengan sub proses atau proses bisnis, partisipan, dan variabel yang digunakan untuk mengeksekusi proses bisnis tersebut.

Pertanyaan terkait dengan sub proses atau proses: Sub proses apa saja yang terkait dengan proses "X (misal proses rekrutmen)?" (lihat gambar 3). Sub proses apa saja yang terkait dengan proses "X (misal rekrutmen)" yang dilakukan oleh "Q (misal departemen yang mengajukan kebutuhan pegawai)?” (lihat gambar 4).
Pertanyaan terkait dengan partisipan yang terlibat dalam proses atau sub proses tertentu. Siapa performer dari sub proses "Y (misal sub proses pengecekan latar belakang pelamar kerja)" pada proses "X (misal proses rekrutment)?" (lihat gambar 5).

Pertanyaan terkait dengan variabel yang digunakan dalam suatu proses atau sub proses tertentu. Data apa saja yang harus dikirim untuk melakukan eksekusi proses "X (e.g., proses penjualan)?" (lihat gambar 6).

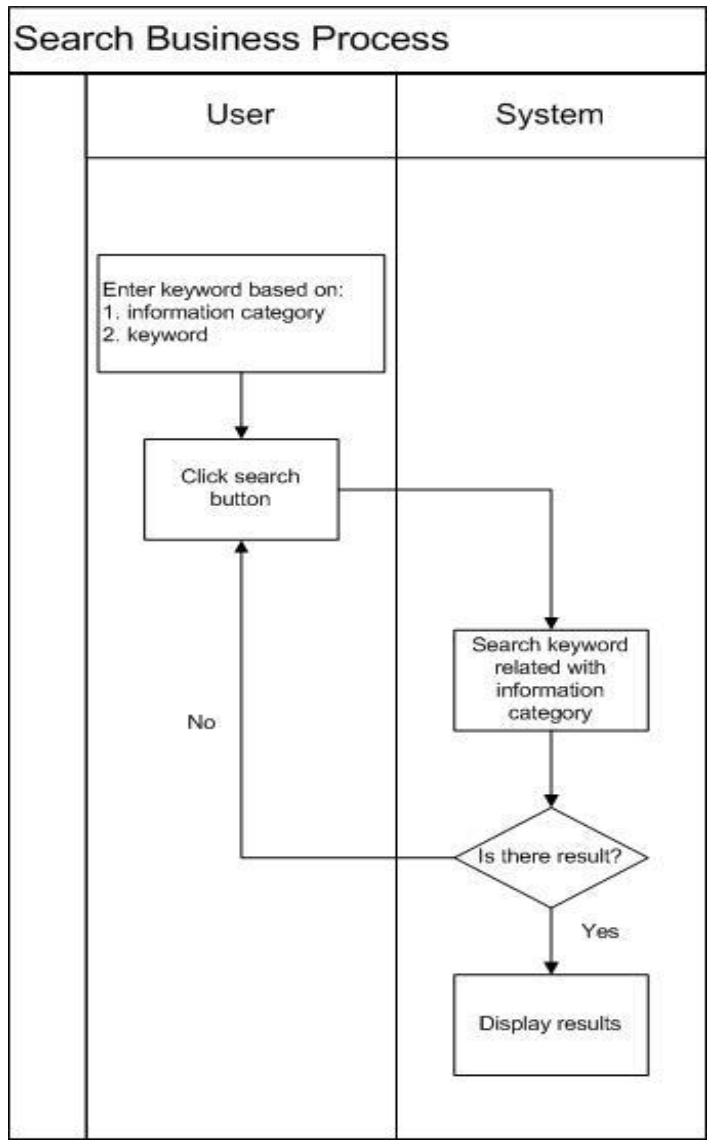

Gambar 2. Diagram cross-functional flow chart proses pencarian.

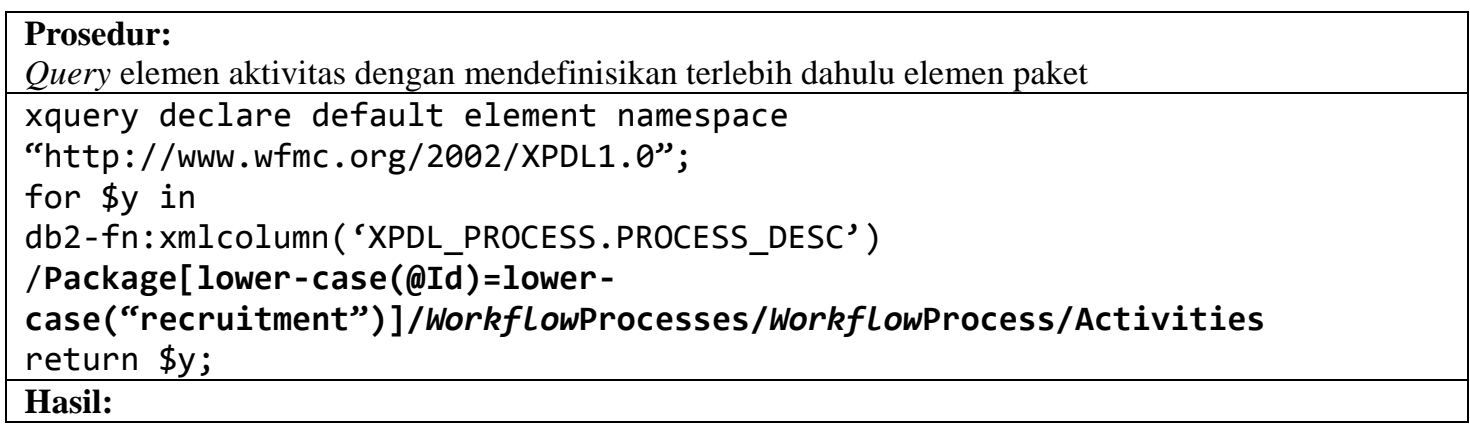




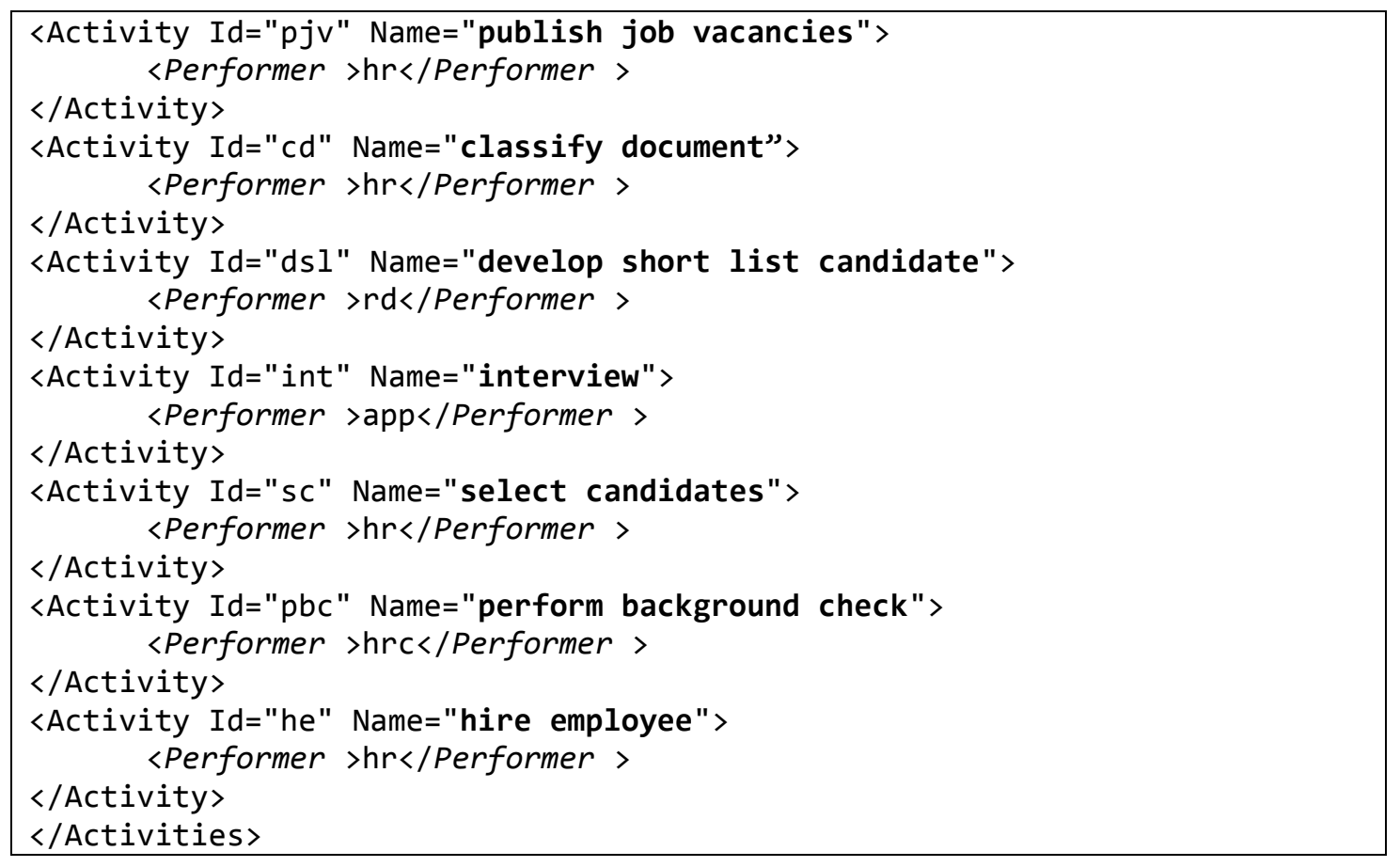

Gambar 3. Pertanyaan terkait proses.

\begin{tabular}{l} 
Prosedur: \\
Pilih atribut nama pelaksana/pengimplementasi/eksekutor proses dengan menentukan elemen paket \\
dan memasukkan nama performer-nya \\
\hline xquerydeclare default element namespace "http://wWw.wfmc.org/2002/XPDL1.0"; \\
for \$y in fn:distinct-values(db2- \\
fn:xmlcolumn('XPDL_PROCESS.PROCESS_DESC')/Package[@Id="recruitment"]/WorkfL \\
owProcesses/WorkfLowProcess/Activities/Activity[Performer ="rd"]/@Name) \\
return \$y; \\
\hline Hasil: \\
communicate_need \\
develop short list candidate
\end{tabular}

Gambar 4. Pertanyaan terkait sub proses.

\section{Prosedur:}

Cari elemen performer dengan menentukan terlebih dahulu elemen paketnya xquery declare default element namespace

"http://www.wfmc.org/2002/XPDL1.0";

for $\$ y$ in $f n:$ distinct-values(db2-

$\mathrm{fn}$ :xmlcolumn ('XPDL_PROCESS.PROCESS_DESC')/Package[lower-case(@Id)=lowercase("recruitment")]/WorkflowProcesses/WorkflowProcess/Activities/Activity [ lower-case (@Name)=lower-case ("perform background check")]/Performer ) return \$y;

\section{Hasil:}

Hrc (Human Resource Consulting)

Gambar 5. Pertanyaan terkait partisipan yang terlibat dan proses dan sub proses.

\section{Prosedur:}

Find the data field identifier by defining the package element

xquery declare default element namespace

"http://www.wfmc .org/2002/XPDL1.0"; 


\begin{tabular}{|l|}
\hline for \$y in fn:distinct-values(db2- \\
fn:xmlcolumn('XPDL_PROCESS.PROCESS_DESC' )/Package[@Id="Sales_Order_Processi \\
ng"]/WorkfLowProcesses/WorkfLowProcess/DataFields/DataField/@Id) return \$y; \\
\hline Hasil: \\
\hline Stock_Status \\
Credit_Status \\
Partial_Ship_Status \\
No_Of_Stocked_Items \\
Customer_Name \\
Product_Name \\
Order_Quantity \\
No_Of_Items_To_Produce \\
\hline
\end{tabular}

Gambar 6. Pertanyaan terkait variabel yang digunakan dalam proses dan sub proses.

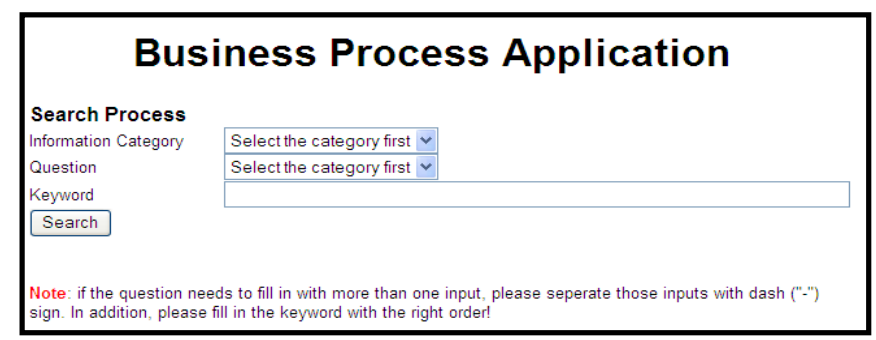

Gambar 7. Tampilan antar muka pencarian.

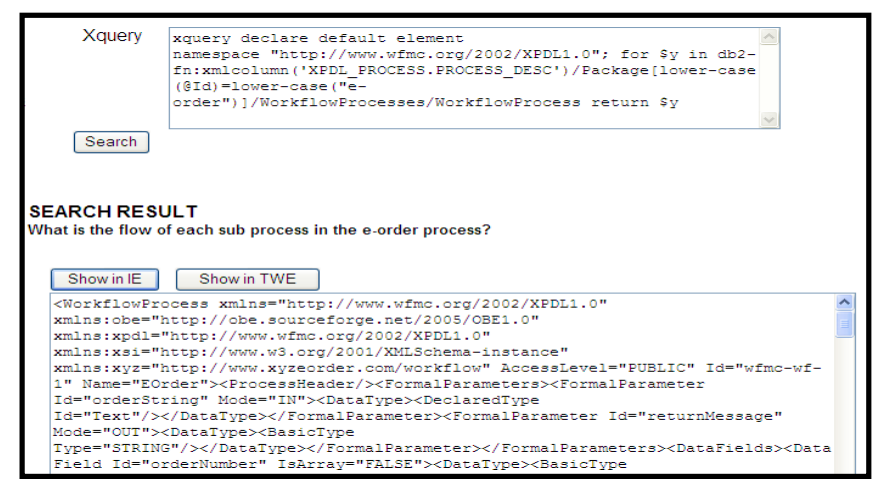

Gambar 8. Tampilan antar muka hasil pencarian.

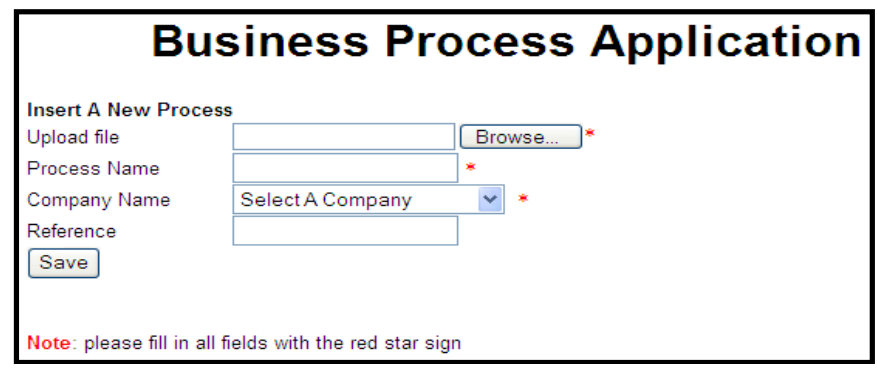

Gambar 5. Tampilan antar muka menambah proses baru.

Dari hasil query di atas dengan menggunakan XQuery, pengguna dapat mencari proses dengan lebih mudah pada proses deskripsi XPDL. Salah satu keterbatasan dari pencarian proses pada struktur file XML adalah ketergantungan pencarian pada nama aktivitas atau identifier. Sebagai contoh ketika mencari "sub proses apa saja yang terkait pada proses penjualan mobil yang melibatkan invoice?", maka untuk menjawabnya harus dilihat dan dicari nama 
atribut pada elemen 〈activity> dan $\langle$ DataField>. Selain itu, penggunaan Xquery menimbulkan isu mengenai kualitas dari hasil pencarian sebagai contoh pencarian kata "owe" akan menghasilkan hasil pencarian termasuk kata "power" yang tidak relevan dengan kata kunci yang dicari oleh pengguna. Kemungkinan besar hal ini dapat diatasi dengan menggunakan fulltextXQuery [9] yang direncanakan sebagai lanjutan dari penelitian ini.

Pengguna dapat mengelola (menyimpan, menghapus, mengubah, dan mengambil) proses bisnis pada sistem pengelolaan proses bisnis mengacu pada MIT process handbook ini. Saat ini, deskripsi proses bisnis disimpan dalam format XPDL. Namun kedepannya dimungkinkan penyimpanan dalam format lainnya. Dalam melakukan proses pencarian, sistem ini menggunakan XQuery. Pengguna dapat mencari suatu proses dengan memasukkan kategori informasi, pertanyaan terkait kata kunci dan kata kunci itu sendiri (gambar 7). Kemudian, sistem akan menampilkan hasil pencarian (gambar 8). Sebagai tambahan pengguna juga dapat menyimpan deskripsi proses bisnis baru dengan mengunggah file XPDL ke dalam sistem (gambar 5). IBM DB2-Express $\mathrm{C}$ digunakan untuk menyimpan file deskripsi XPDL dikarenakan IBM DB2 dapat mengelola data XML. Daftar proses yang digunakan di sistem ini diambil dari MIT Process Handbook dan buku teks untuk mata kuliah ERP (Enterprise Resource Planning) pada jurusan Sistem Informasi.

\section{Kesimpulan}

Riset ini menghasilkan prototipe sistem pengelolaan proses bisnis berbasis XML dan mengacu pada MIT Process Handbook. Tujuan dari sistem ini untuk membantu pengguna dalam menyimpan, menyebarluaskan, melakukan query, dan mengeksekusi proses bisnis. Sistem ini menggunakan XPDL yang merupakan standar bahasa dalam pendefinisian dan pengeksekusian proses bisnis. Metode pencarian proses bisnis pada sistem ini mengeksploitasi XQuery. Proses bisnis yang digunakan adalah proses-proses yang digunakan dalam pengajaran mata kuliah Sistem Informasi, sehingga nantinya sistem ini dapat digunakan oleh mahasiswa Sistem Informasi untuk mempelajari proses bisnis.

Isu terkait dengan pekerjaan atau penelitian yang akan datang yakni diperlukan studi lebih lanjut yang memungkinkan untuk melakukan hybrid queries yang dapat mengkombinasikan pencarian struktural dengan menggunakan kata kunci dan informasi lainnya yang terkait dengan kata kunci tersebut, misalkan dengan menggunakan XQuery full-text. Selain itu dibutuhkan konsep generalisasi dan spesialisasi dalam perancangan dan pengeksekusian query sehingga pengguna dapat lebih mengeksplor pencarian yang diinginkan. Oleh karena itu, diperlukan definisi proses aljabar generalisasi dan spesialisasi dengan tujuan untuk melakukan pendefinisian struktur data yang terlibat dalam proses dan query language.

\section{Referensi}

[1] WfMC Website, http://www.wfmc.org/, retrieved August 19, 2009.

[2] T.W. Malone, K.G Crowston, G. Herman., Organizing Business Knowledge: The MIT Process Handbook, The MIT Press, Cambridge, 2003.

[3] J.F. Chang, Business Process Management System: Strategy and Implementation, Auerbach Publications, New York, 2006,

[4] W.M.P. Van Der Aalst, Patterns and XPDL: A Critical Evaluation of the XML, Process Definition Language, QUT Technical Report FIT-TR-2003-06, Queensland University of Technology, Brisbane, 2003.

[5] W.M.P. Van Der Aalst and Kees Van Hee, Workflow Management Models, Methods and Systems, MIT Press, England, 2002.

[6] J. Vanhatalo, J. Koehler, F. Leymann. "Repository for Business Processes and Arbitrary Associated Metadata" In Proceedings of the BPM Demo Session at the Fourth International Conference on Business Process Management, pp. 25-31, 2006.

[7] B. Wetzstein, Z. Ma, F. Leymann, "Towards Measuring Key Performance Indicators of Semantic Business Processes" In BIS, pp. 227-238, 2008.

[8] A. Moller and M. Schwartzbach, An Introduction to XML and Web Technologies, Addison Wesley, Denmark, 2006.

[9] S. Amer-Yahia, C. Botev, S.Buxton, P. Case, J. Doerre, D. McBeath, M. Rys, J. Shanmugasundaram (Eds.), XQuery 1.0 and XPath 2.0 Full-Text, W3C, http://www.w3.org/TR/2005/WD-xqueryfull-text-20051103/, retrieved September 22, 2009. 